\title{
Hepatocyte Growth Factor
}

National Cancer Institute

\section{Source}

National Cancer Institute. Hepatocyte Growth Factor. NCI Thesaurus. Code C20428.

Hepatocyte growth factor (728 aa, $\sim 83 \mathrm{kDa}$ ) is encoded by the human HGF gene. This protein is involved in both the modulation of hepatocyte proliferation and growth factor receptor signaling in hepatocytes and many other cell types. 